This is an author produced version of a paper published in Remote Sensing Letters.

This paper has been peer-reviewed and is proof-corrected, but does not include the journal pagination.

Citation for the published paper:

Karin Nordkvist, Ann-Helen Granholm, Johan Holmgren, Håkan Olsson \& Mats Nilsson. (2012) Combining optical satellite data and airborne laser scanner data for vegetation classification. Remote Sensing Letters. Volume: 3, Number: 5, pp 393-401.

http://dx.doi.org/10.1080/01431161.2011.606240.

Access to the published version may require journal subscription.

Published with permission from: Taylor \& Francis.

Standard set statement from the publisher:

This is an Author's Accepted Manuscript of an article published in REMOTE SENSING LETTERS, 6 Sept 2011, copyright Taylor \& Francis, available online at: http://www.tandfonline.com/10.1080/01431161.2011.606240.

Epsilon Open Archive http://epsilon.slu.se 


\title{
Combining optical satellite data and airborne laser scanner data for vegetation classification
}

\author{
Karin Nordkvist, Ann-Helen Granholm, Johan Holmgren, Håkan Olsson and Mats Nilsson \\ Swedish University of Agricultural Sciences, Department of Forest Resource Management, SE-90183 Umeå, \\ Sweden \\ Published 2012 in Remote Sensing Letters 3(5), 393-401
}

\begin{abstract}
The aim of this study was to investigate to which degree the accuracy of vegetation classification could be improved by combining optical satellite data and airborne laser scanner (ALS) data, compared with using satellite data only. A Satellite Pour l'Observation de la Terre (SPOT) 5 scene and Leica ALS 50-II data from 2009, covering a test area in the mid-Sweden (latitude $60^{\circ} 43^{\prime} \mathrm{N}$, longitude $16^{\circ} 43^{\prime} \mathrm{E}$ ), were used in maximum likelihood and decision tree classifications. Training and validation data were obtained from the interpretation of digital aerial photo stereo models. Combination of SPOT and ALS data gave classification accuracies up to $72 \%$, compared with $56 \%$ using only SPOT data. This indicates that integrating features from large area laser scanning may lead to significant improvements in satellite data-based vegetation classifications.
\end{abstract}

\section{Introduction}

The combined use of satellite imagery and airborne laser scanner (ALS) data in vegetation mapping is promising, since it makes use of both the spectral information in the optical satellite image and the threedimensional information in the ALS data.

The EU Habitats Directive has set new and high standards for how protected sites and valuable habitats should be selected and monitored (European Commission 2000, European Commission/DG Environment 2007). In Sweden, with large forest areas, this requires efficient methods for identifying valuable sites over large areas at low costs. The currently available vegetation maps, produced by aerial photo interpretation, cover less than $50 \%$ of the land area in Sweden, and there is currently no funding available for producing a national vegetation map with entirely manual methods.

Automated satellite image classification is an established method for producing large area land-cover maps and estimations of forest variables, for example, in the Swedish national version of the European Coordination of Information on the Environment (CORINE) Land Cover database (Hagner and Reese 2007); a statewide land-cover mapping of Wisconsin (Reese et al. 2002); the Land Cover Map of Great Britain (LCMGB) (Fuller et al. 1994); and Moderate Resolution Imaging Spectroradiometer (MODIS) Land Cover (Friedl et al. 2002), just to mention a few. The accuracy obtained for such products based on the twodimensional optical data like Landsat Thematic Mapper (TM) is, however, limited. ALS data have proved useful in the mapping of certain vegetation types such as mires (Korpela et al. 2009). Several studies have shown the benefits of combining ALS data with different kinds of imagery, for example, for estimations of forest variables (Hyde et al. 2006, Holmgren et al. 2008, Erdody and Moskal 2010), and for classification and mapping of forests (Hill and Thomson 2005, Dalponte et al. 2008, Ke et al. 2010), rangelands (Bork and Su 2007), urban areas (Haala and Brenner 1999) and coastal and estuarine areas (Chust et al. 2008, Kempeneers et al. 2009). Also imaging radar has been used in combination with optical satellite data, for example, for mapping of deforestation in Brazil (Rignot et al. 1997).

Beginning in 2009, the Swedish National Land Survey (NLS) is collecting laser scanner data for most of the country. Although the main purpose is the production of a new, national Digital Elevation Model (DEM), the nation-wide coverage of laser data might also be a resource for future vegetation mapping.

The objective of our study was to investigate the use of combining ALS data and images from the Satellite Pour l'Observation de la Terre (SPOT) 5 in a vegetation classification. A SPOT scene from late May 2009 , covering an area west of Gävle in the midSweden, was used together with the ALS data from the same period. Focus was on mapping forest vegetation and mires according to the classification system of the Swedish national version of CORINE Land Cover database (Engberg 2005). 


\section{Material and methods}

\subsection{Study area}

The $25 \times 50 \mathrm{~km} 2$ study area is located west of Gävle in mid-Sweden around latitude $60^{\circ} 43^{\prime} \mathrm{N}$, longitude $16^{\circ}$ $43^{\prime}$ E (figure 1). It is mainly covered by managed hemiboreal forests and mires, here defined as peataccumulating wetlands with less than $30 \%$ canopy cover. These forests are dominated by Scots pine (Pinus sylvestris), Norway spruce (Picea abies) and birch (Betula spp.).

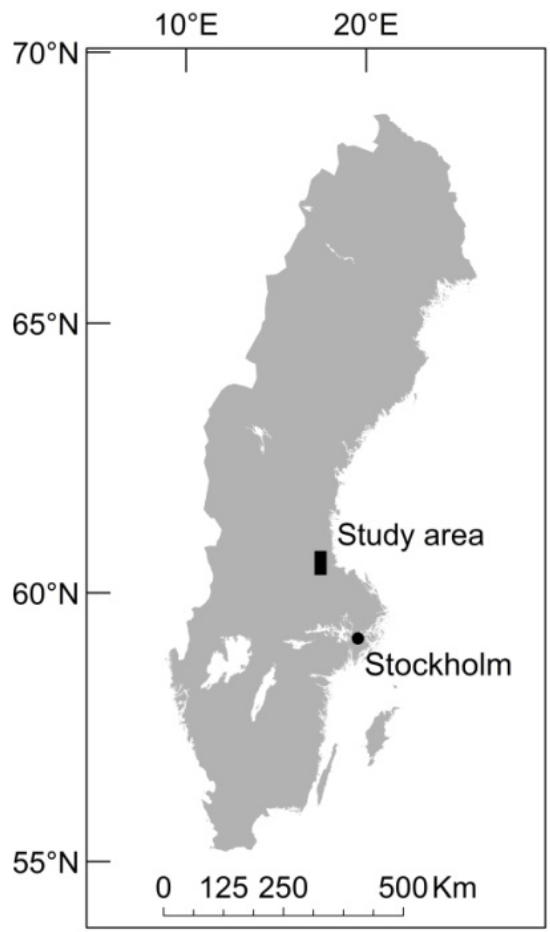

Figure 1. Map of the study area.

\subsection{Remote-sensing data}

The optical satellite data used in this study was a SPOT 5 HRG XS scene from 31May 2009. The pixel size was $10 \mathrm{~m} \times 10 \mathrm{~m}$ for the green, red and near-infrared bands and $20 \mathrm{~m} \times 20 \mathrm{~m}$ for the shortwave infrared band. The image has been geometrically precision corrected to the grid system Swedish Reference Frame 1999 (SWEREF 99), with an error of less than 0.5 pixels. Within the framework of the national DEM production, NLS performed a laser scanning of the study area during 29-31 May 2009 using a Leica ALS 50-II scanner carried by a fixed-wing aircraft. The flying altitude was approximately $2300 \mathrm{~m}$, the average point density $1.6 \mathrm{~m}-2$ and the maximum scanning angle $\pm 20^{\circ}$.

\subsection{Vegetation reference data}

Ground-truth data were collected through the interpretation of colour-infrared aerial photos. The photos were acquired by NLS at $4800 \mathrm{~m}$ above the average ground level in 2008 and 2009 using a Z/I Digital Mapping Camera (DMC) and interpreted in a digital photogrammetric work station. While a basic sample of images was randomly distributed in the study area, a set of additional images were selected from areas where the less frequent deciduous and mixed forest classes are more common in order to represent all classes. Class proportions in the groundtruth data set are therefore not entirely representative for the region. Within the stereo images, 1548 circular sample plots with $10 \mathrm{~m}$ radius were distributed in a grid with $500 \mathrm{~m}$ spacing and a randomly selected starting point. The following data were registered per plot: mean tree height, tree species composition (percentage of canopy cover), diffuse canopy cover (percentage) and vegetation class. Canopy cover is defined as the area of the ground covered by a vertical projection of the canopy (Jennings et al. 1999). Diffuse canopy cover means the total vertical projection of the tree crowns on the ground, including any gaps within the crowns (Allard et al. 2003). The classification scheme has seven classes based on the refined Swedish national version of the European CORINE Land Cover database (Engberg 2005). Unlike in CORINE, no minimum mapping unit was used in this study. Class definitions are given in table 1. Due to few training areas, the classes coniferous, deciduous and mixed forest on mire, that is forest meeting the criteria of $30 \%$ canopy cover and $5 \mathrm{~m}$ tree height but growing on mire, were excluded from the classification and are not shown in table 1 . Plots where the dominating class covered less than $70 \%$ were excluded from the reference data set. Large spectral outliers were examined closer by visual interpretation of the satellite image and aerial photos and excluded if the presence of roads, water, large gaps between trees and so on could explain the spectral anomalies. After exclusion of outliers, the data set consists of 780 plots. From each class, two-thirds of the plots were randomly selected as training areas and the remaining third was used for validation.

\subsection{Processing of remote-sensing data}

Laser returns were classified as ground or vegetation returns using a progressive Triangulated Irregular Network (TIN) densification method (Axelsson 1999, 2000), implemented in the TerraScan software (Terrasolid Ltd., Helsinki, Finland) (Soininen 2004). A DEM was estimated by linear TIN interpolation with the laser returns classified as ground hits. First step, ground elevation was calculated in $0.5 \mathrm{~m}$ raster cells as 
the mean elevation of ground hits within each cell. Second, empty cells were assigned elevation values by TIN interpolation of the filled cells. The height value (dz) of a laser return was computed as the difference between the z-value of the laser return and the z-value of the DEM.

Table 1. Class definitions.

\begin{tabular}{|c|c|c|c|c|c|c|}
\hline \multirow{2}{*}{ Class } & \multirow{2}{*}{$\begin{array}{c}\text { Canopy } \\
\text { cover }(\%)\end{array}$} & \multirow{2}{*}{$\begin{array}{l}\text { Tree height } \\
\text { (m) }\end{array}$} & \multicolumn{2}{|c|}{ Species composition (\%) } & \multirow{2}{*}{$\begin{array}{l}\text { No. of sample } \\
\text { plots, training }\end{array}$} & \multirow{2}{*}{$\begin{array}{l}\text { No. of sample } \\
\text { plots, evaluation }\end{array}$} \\
\hline & & & Coniferous & Deciduous & & \\
\hline Clear cut $\dagger$ & $0-100$ & $<2$ & $0-100$ & $0-100$ & 87 & 43 \\
\hline Young & $0-100$ & $2-5$ & $0-100$ & $0-100$ & 23 & 12 \\
\hline $\begin{array}{l}\text { Coniferous 5- } \\
15 \mathrm{~m}\end{array}$ & $\geq 30$ & $>5, \leq 15$ & $\geq 70$ & $<30$ & 94 & 47 \\
\hline $\begin{array}{l}\text { Coniferous } \\
>15 \mathrm{~m}\end{array}$ & $\geq 30$ & $>15$ & $\geq 70$ & $<30$ & 185 & 93 \\
\hline Deciduous & $\geq 30$ & $>5$ & $<30$ & $\geq 70$ & 81 & 41 \\
\hline Mixed & $\geq 30$ & $>5$ & $30-70$ & $30-70$ & 23 & 11 \\
\hline Mire & $\leq 30$ & any & $0-100$ & $0-100$ & 27 & 13 \\
\hline
\end{tabular}

Notes: $†$ The plot should show traces of felling, e.g. stumps, machine tracks and debris. $\$$ Peat-accumulating wetland. This ground type is not allowed for any other class.

Laser data were extracted in $10 \mathrm{~m} \times 10 \mathrm{~m}$ grid cells coinciding with the SPOT pixels. A height threshold of $10 \%$ of the maximum laser height in each cell and $\geq$ $1.0 \mathrm{~m}$ was applied in order to separate canopy returns from returns of ground, stones and low vegetation. Several features were extracted from the laser data within each raster cell, based on the $\mathrm{dz}$ distribution of laser returns above the height threshold: $10^{\text {th }}$ percentile $\left(\mathrm{P}_{10}\right), 20^{\text {th }}$ percentile $\left(P_{20}\right), \ldots, 90^{\text {th }}$ percentile $\left(P_{90}\right), 95^{\text {th }}$ percentile $\left(P_{95}\right)$ and $100^{\text {th }}$ percentile $\left(P_{100}\right)$. A vegetation ratio $(V)$ was calculated as the ratio between the number of laser returns above the height threshold and the total number of returns.

\subsection{Classification and accuracy assessment}

Classification was done with the ENVI software version 4.7 (ITT Visual Information Solutions, Boulder, CO, USA), using the maximum likelihood method. Image data for the training and validation plots were extracted from the SPOT image and the ALS rasters with nearest-neighbour sampling. A first classification was done with the four SPOT bands, and different combinations of height percentiles and/or vegetation ratio from the ALS data were tested as additional bands. Classification with only ALS data was tested in order to better understand the influence of these data on the result. A decision tree classification was also tested. In the first step, a threshold on $\mathrm{V}$ was used to split the pixels into two groups: (1) clear-cuts and mires (low $V$ ) and (2) other classes. The threshold $\mathrm{V}=0.31$ was selected as the value giving the largest number of correctly classified plots in the training data. Second, a maximum likelihood classification with the SPOT bands as predictors was made on each group separately. Pixels classified as coniferous forest were then classified as 5-15 $\mathrm{m}$ or $>15 \mathrm{~m}$ using the threshold obtained from linear regression between $P_{90}$ and aerial photointerpreted tree height.

\section{Results}

Classification using only the four SPOT bands gave an overall accuracy of $55.8 \%$. The error matrix (table 2) shows that many clear-cuts were classified as young forest, and that the two coniferous classes were often mixed up.

When looking at the entire reference data set, Pearson correlation coefficient between $\mathrm{V}$ and aerial photo-interpreted canopy cover was $84.3 \%$. The correlation between height percentiles and mean tree height ranged from $59.5 \%$ to $71.9 \%$ for $P_{10}$ to $P_{50}$ and decreased slightly for higher percentiles. For the two coniferous classes, the highest correlation, $93.2 \%$, was found for $P_{90}$. Using $P_{50}$ and $V$ as additional bands in the classification resulted in an overall accuracy of $70.0 \%$. Without $V$ the accuracy was $65.8 \%$. The improvement is mainly due to less confusion between clear-cuts and young forest and between the two coniferous classes. Table 3 shows the error matrix.

When using ALS data alone, $P_{50}$ and $P_{90}$ gave good results for coniferous forest and mire, but the overall accuracy was only $50.4 \%$ and the result was particularly bad for deciduous forest and clear-cuts. Adding $V$ improved the result for these two classes, but the overall accuracy remained low, $58.5 \%$. 
The highest overall accuracy, $71.9 \%$, was obtained with the decision tree. The majority-filtered classification image is similar to the one from the best maximum likelihood classification (figure 2(d)), but slightly more heterogeneous and possibly with some more confusion between young forest and coniferous forest 5-15 m. Kappa analysis of the error matrices for classification with only SPOT data and for the decision tree classification (SPOT and ALS data) indicates that the latter method is significantly better at a confidence level higher than $99 \%$.

Overall classification accuracies for different band combinations are shown in table 4, together with producer's accuracies for each class. Classification images for a part of the study area are shown in figure 2 together with the SPOT 5 image and the $P_{50}$ raster. After validation of the result, post-processing of the classified images was made with a $5 \times 5$ pixels majority filter.

Table 2. Error matrix for maximum likelihood classification using only SPOT data.

\begin{tabular}{|c|c|c|c|c|c|c|c|c|}
\hline \multirow{2}{*}{$\begin{array}{l}\text { Classification } \\
\text { data }\end{array}$} & \multicolumn{7}{|c|}{ Validation data } & \multirow{2}{*}{$\begin{array}{l}\text { User's } \\
\text { accuracy (\%) }\end{array}$} \\
\hline & Clear-cut & Young & $\begin{array}{l}\text { Coniferous 5-15 } \\
\mathrm{m}\end{array}$ & Coniferous $>15 \mathrm{~m}$ & Deciduous & Mixed & Mire & \\
\hline Clear cut & 24 & 1 & 0 & 0 & 0 & 0 & 2 & 88.9 \\
\hline Young & 13 & 8 & 4 & 1 & 2 & 1 & 1 & 26.7 \\
\hline $\begin{array}{l}\text { Coniferous 5-15 } \\
\mathrm{m}\end{array}$ & 1 & 0 & 14 & 20 & 3 & 0 & 0 & 36.8 \\
\hline $\begin{array}{l}\text { Coniferous }>15 \\
\mathrm{~m}\end{array}$ & 1 & 0 & 23 & 53 & 1 & 3 & 0 & 65.4 \\
\hline Deciduous & 0 & 3 & 1 & 5 & 29 & 0 & 0 & 76.3 \\
\hline Mixed & 0 & 0 & 5 & 13 & 6 & 7 & 0 & 22.6 \\
\hline Mire & 4 & 0 & 0 & 1 & 0 & 0 & 10 & 66.7 \\
\hline $\begin{array}{l}\text { Producer's } \\
\text { accuracy (\%) }\end{array}$ & 55.8 & 66.7 & 29.8 & 57.0 & 70.7 & 63.6 & 76.9 & $\begin{array}{l}\text { Overall } \\
\text { accuracy } \\
55.8\end{array}$ \\
\hline
\end{tabular}

Table 3. Error matrix for maximum likelihood classification using SPOT data, $\mathrm{P}_{50}$ and V.

\begin{tabular}{|c|c|c|c|c|c|c|c|c|}
\hline \multirow[b]{2}{*}{ Classification data } & \multicolumn{7}{|c|}{ Validation data } & \multirow{2}{*}{$\begin{array}{l}\text { User's } \\
\text { accuracy }(\%)\end{array}$} \\
\hline & Clear-cut & Young & $\begin{array}{l}\text { Coniferous 5-15 } \\
\mathrm{m}\end{array}$ & $\begin{array}{l}\text { Coniferous }>15 \\
\mathrm{~m}\end{array}$ & Deciduous & Mixed & Mire & \\
\hline Clear cut & 33 & 0 & 0 & 1 & 0 & 0 & 4 & 86.8 \\
\hline Young & 3 & 12 & 4 & 1 & 3 & 0 & 0 & 52.2 \\
\hline Coniferous $5-15 \mathrm{~m}$ & 0 & 0 & 31 & 5 & 4 & 3 & 0 & 72.1 \\
\hline Coniferous $>15 \mathrm{~m}$ & 1 & 0 & 7 & 67 & 3 & 3 & 0 & 82.7 \\
\hline Deciduous & 0 & 0 & 1 & 3 & 27 & 2 & 0 & 81.8 \\
\hline Mixed & 0 & 0 & 4 & 16 & 4 & 3 & 0 & 11.1 \\
\hline Mire & 6 & 0 & 0 & 0 & 0 & 0 & 9 & 60.0 \\
\hline $\begin{array}{l}\text { Producer's accuracy } \\
(\%)\end{array}$ & 76.7 & 100 & 66.0 & 72.0 & 65.9 & 27.3 & 69.2 & $\begin{array}{l}\text { Overall } \\
\text { accuracy } \\
70.0\end{array}$ \\
\hline
\end{tabular}




\section{Discussion}

The objective of this study was to investigate to which degree a vegetation classification using optical satellite images could be improved by integrating ALS data. The combined use of these two data sources increased the classification accuracy by $16 \%$ compared with those using only satellite data. The highest overall accuracy was obtained when using $P_{90}$ and $V$ together with SPOT data in a decision tree. ALS data helped distinguish between height classes with similar spectral signatures, while optical satellite data were important for species discrimination.
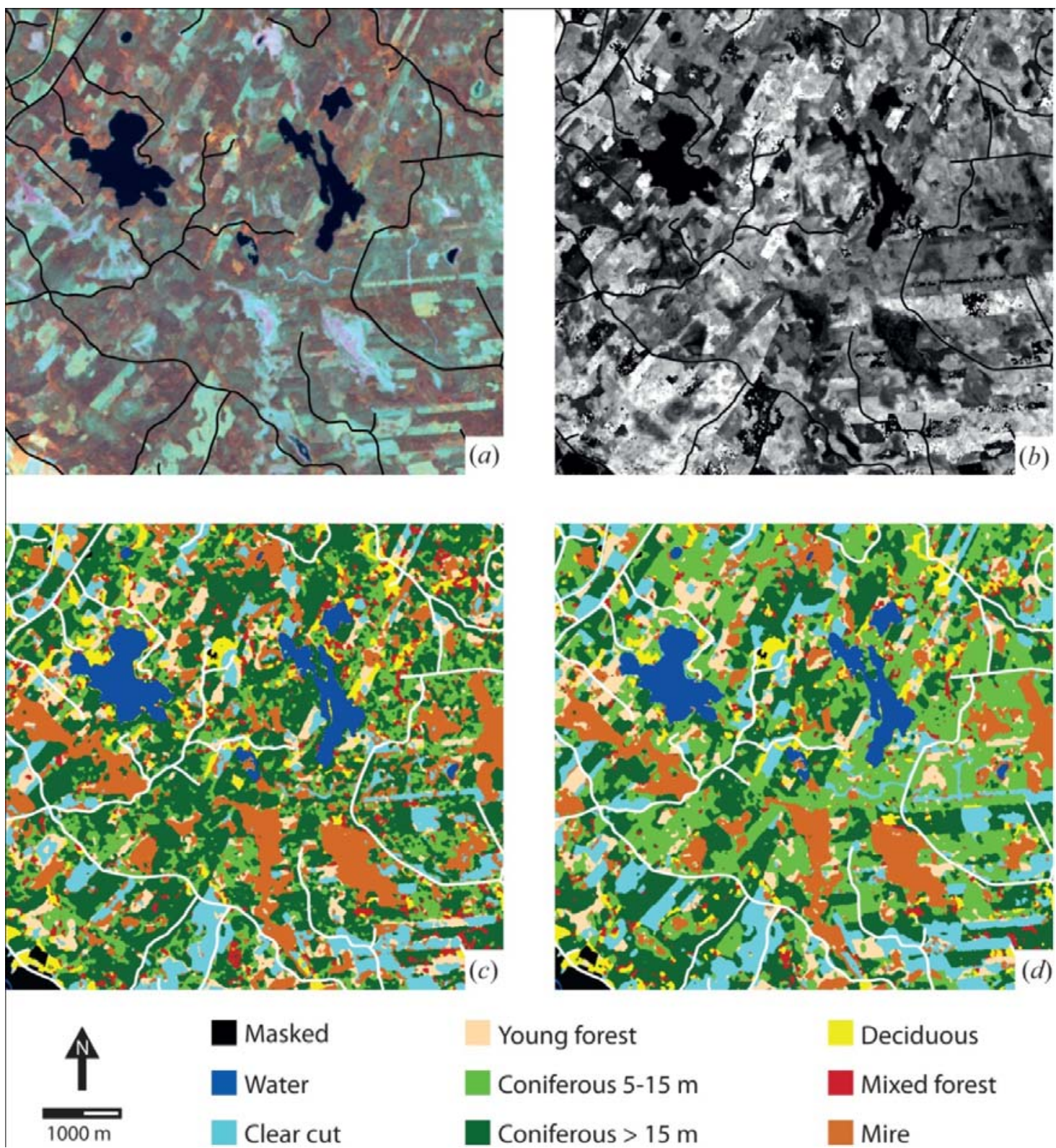

$P_{50}$ and $P_{90}$ alone did not work well for separating clear-cuts, but the result improved from $11.6 \%$ to $41.9 \%$ when adding $V$. If one single tree, or part of a tree, is present in a clear-cut pixel, the height percentiles will be strongly affected by that tree since most of the lower vegetation will fall below the height threshold and will not count as vegetation hits. The height percentiles may therefore have values similar to still be low, which explains the improvement in accuracy when this variable was used in the classification. those in higher forest classes. The vegetation ratio will

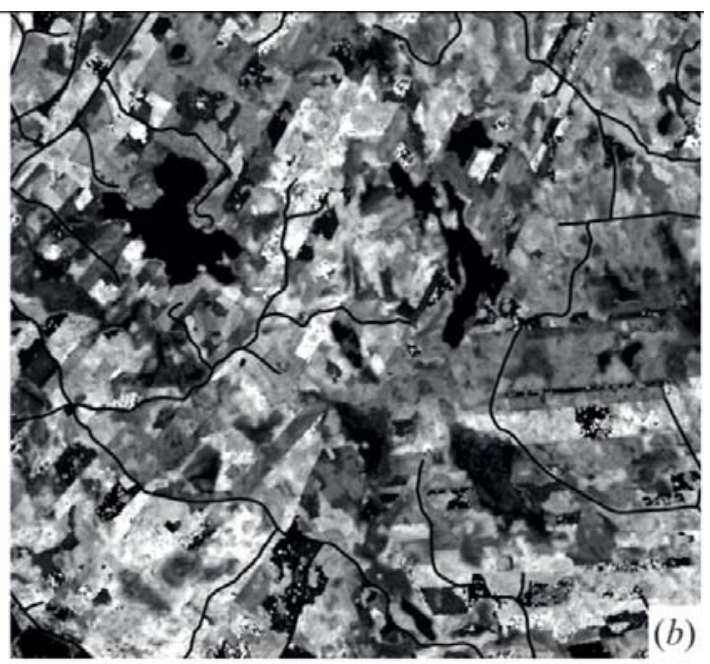

gure 2. A $6.6 \times 6.2 \mathrm{~km}$ part of the study area. (a) The SPOT image, (b) the $P_{50}$ raster, (c) classification using SPOT data and $(d)$ classification using SPOT data together with $P_{50}$ and $V$. Water and roads are from the Swedish National Land Survey's 
topographic map and road map. Urban and agricultural areas from the topographic map are masked out. A $5 \times 5$ pixels majority filter has been applied to the classified images.

The low accuracy when using only SPOT data is partly due to confusion between the two height classes of coniferous forest. There is little spectral difference between these classes, and the height information from ALS data is necessary in order to separate them from each other. Clear-cuts that are old enough to have some vegetation are spectrally close to young forest, which might explain the confusion between these two classes. In addition, it is difficult to accurately measure the height of small trees in aerial photo stereo models. This may cause errors in the reference data set and might be one reason for the relatively low classification accuracies. These errors, however, have no implications on the overall conclusion that using features from large area laser scanning would lead to significant improvements in satellite data-based landcover classifications.

\section{Acknowledgements}

This work was financially supported by the Swedish National Space Board and the Swedish Environmental Protection Agency. We thank the Swedish NLS (Lantmäteriet) for the ALS data and three anonymous reviewers for their constructive comments.

Table 4. Over-all accuracy and classwise producer's accuracies (\%) for different band combinations.

\begin{tabular}{|c|c|c|c|c|c|c|c|c|}
\hline Bands ${ }^{*}$ & Clear cut & Young & $\begin{array}{l}\text { Coniferous } 5-15 \\
\mathrm{~m}\end{array}$ & Coniferous $>15 \mathrm{~m}$ & Deciduous & Mixed & Mire & Over-all \\
\hline $\mathrm{S} 1-\mathrm{S} 4$ & 55.8 & 66.7 & 29.8 & 57.0 & 70.7 & 63.6 & 76.9 & 55.8 \\
\hline $\mathrm{S} 1-\mathrm{S} 4, P_{50}$ & 58.1 & 83.3 & 61.7 & 72.0 & 63.4 & 36.4 & 76.9 & 65.8 \\
\hline $\mathrm{S} 1-\mathrm{S} 4, V$ & 69.8 & 75.0 & 36.2 & 52.7 & 68.3 & 36.4 & 76.9 & 56.5 \\
\hline $\mathrm{S} 1-\mathrm{S} 4, P_{50}, V$ & 76.7 & 100 & 66.0 & 72.0 & 65.9 & 27.3 & 69.2 & 70.0 \\
\hline$P_{50}, P_{90}$ & 11.6 & 16.7 & 74.5 & 80.6 & 2.44 & 18.2 & 84.6 & 50.4 \\
\hline$P_{50}, P_{90}, V$ & 41.9 & 83.3 & 63.8 & 77.4 & 17.1 & 36.4 & 84.6 & 58.5 \\
\hline decision tree† & 67.4 & 66.7 & 68.1 & 77.4 & 70.7 & 63.6 & 76.9 & 71.9 \\
\hline
\end{tabular}

${ }^{*} \mathrm{~S} 1-\mathrm{S} 4$ are the four SPOT bands, $P_{50}$ and $P_{90}$ are the $50^{\text {th }}$ and $90^{\text {th }}$ height percentiles, and $V$ is the vegetation ratio. $\dagger$ The decision tree uses $V, P_{90}$ and the four SPOT bands as predictors.

\section{References}

ALLARD, A., NILSSON, B., PRAMBORG, K., STÅHL, G. and SUNDQUIST, S., 2003, Manual for aerial photo interpretation in the National Inventory of Landscapes in Sweden. Umeå: Department of Forest Resource Management and Geomatics, Swedish University of Agricultural Sciences.

AXELSSON, P.E., 1999, Processing of laser scanner data - algorithms and applications. ISPRS Journal of Photogrammetry and Remote Sensing, 54, pp. $138-147$.

AXELSSON, P.E., 2000, DEM generation from laser scanner data using adaptive TIN models. International Archives of Photogrammetry and Remote Sensing, 33, pp. 110-117.

BORK, E.W. and SU, J.G., 2007, Integrating LIDAR data and multispectral imagery for enhanced classification of rangeland vegetation: A meta analysis. Remote Sensing of Environment, 111, pp. 11-24.
CHUST, G., GALPARSORO, I., BORJA, A., FRANCO, J. and URIARTE, A., 2008, Coastal and estuarine habitat mapping, using LIDAR height and intensity and multi-spectral imagery. Estuarine Coastal and Shelf Science, 78, pp. 633-643.

DALPONTE, M., BRUZZONE, L. and GIANELLE, D., 2008, Fusion of hyperspectral and LIDAR remote sensing data for classification of complex forest areas. IEEE Transactions on Geoscience and Remote Sensing, 46, pp. 1416-1427.

ENGBERG, A., 2005, Produktspecifikation av Svenska CORINE Marktäckedata. Available online at:

http://www.lantmateriet.se/upload/filer/kartor/karto r_och_geografisk_info/GSD-

Produktbeskrivningar/SCMDspec.pdf (accessed 18 March 2011).

ERDODY, T.L. and MOSKAL, L.M., 2010, Fusion of LiDAR and imagery for estimating forest canopy fuels. Remote Sensing of Environment, 114, pp. 725-737. 
EUROPEAN COMMISSION, 2000, Managing Natura 2000 Sites: The provisions of Article 6 of the 'Habitats' Directive 92/43/EEC. Luxembourg: Office for Official Publications of the European Communities. ISBN 92-828-9048-1.

EUROPEAN COMMISSION/DG ENVIRONMENT, 2007, Interpretation manual of European Union habitats. European Commission/DG Environment. EUR27.

FRIEDL, M.A., MCIVER, D.K., HODGES, J.C.F., ZHANG, X.Y., MUCHONEY, D., STRAHLER, A.H., WOODCOCK, C.E., GOPAL, S., SCHNEIDER, A., COOPER, A., BACCINI, A., GAO, F. and SCHAAF, C., 2002, Global land cover mapping from MODIS: algorithms and early results. Remote Sensing of Environment, 83, pp. 287-302.

FULLER, R.M., GROOM, G.B. and JONES, A.R., 1994, The Land Cover Map of Great Britain: an automated classification of Landsat Thematic Mapper data. Photogrammetric Engineering and Remote Sensing, 60, pp. 553-562.

HAALA, N. and BRENNER, C., 1999, Extraction of buildings and trees in urban environments. ISPRS Journal of Photogrammetry and Remote Sensing, 54, pp. 130-137.

HAGNER, O. and REESE, H., 2007, A method for calibrated maximum likelihood classification of forest types. Remote Sensing of Environment, 110, pp. 438-444.

HILL, R.A. and THOMSON, A.G., 2005, Mapping woodland species composition and structure using airborne spectral and LiDAR data. International Journal of Remote Sensing, 26, pp. 3763-3779.

HOLMGREN, J., PERSSON, A. and SÖDERMAN, U., 2008, Species identification of individual trees by combining high resolution LIDAR data with multi-spectral images. International Journal of Remote Sensing, 29, pp. 1537-1552.
HYDE, P., DUBAYAH, R., WALKER, W., BLAIR, J.B., HOFTON, M. and HUNSAKER, C., 2006, Mapping forest structure for wildlife habitat analysis using multi-sensor (LiDAR, SAR/InSAR, ETM+, Quickbird) synergy. Remote Sensing of Environment, 102, pp. 63-73.

JENNINGS, S.B., BROWN, N.D. and SHEIL, D., 1999, Assessing forest canopies and understorey illumination: canopy closure, canopy cover and other measures. Forestry, 72, pp. 59-73.

KE, Y., QUACKENBUSH, L.J. and IM, J., 2010, Synergistic use of QuickBird multispectral imagery and LIDAR data for object-based forest species classification. Remote Sensing of Environment, 114, pp. 1141-1154.

KEMPENEERS, P., DERONDE, B., PROVOOST, S. and HOUTHUYS, R., 2009, Synergy of airborne digital camera and lidar data to map coastal dune vegetation. Journal of Coastal Research, SI 53, pp. 73-82.

KORPELA, I., KOSKINEN, M., VASANDER, H., HOLOPAINEN, M. and MINKKINEN, K., 2009, Airborne small-footprint discrete-return LiDAR data in the assessment of boreal mire surface patterns, vegetation, and habitats. Forest Ecology and Management, 258, pp. 1549-1566.

REESE, H.M., LILLESAND, T.M., NAGEL, D.E., STEWART, J.S., GOLDMANN, R.A., SIMMONS, T.E., CHIPMAN, J.W. and TESSAR, P.A., 2002, Statewide land cover derived from multiseasonal Landsat TM data - A retrospective of the WISCLAND project. Remote Sensing of Environment, 82, pp. 224-237.

RIGNOT, E., SALAS, W.A. and SKOLE, D.L., 1997, Mapping deforestation and secondary growth in Rondonia, Brazil, using imaging radar and Thematic Mapper data. Remote Sensing of Environment, 59, pp. 167-179.

SOININEN, A., 2004, Terra Scan for MicroStation, user's guide. Jyväskylä: Terrasolid Ltd. 